\title{
SOME NEW EUCERINE BEES FROM THE WEST.
}

BY T. D. A. COCKERELL, BOULDER, COLORADO.

Melissodes herricki, n. sp.

o Length about $\mathrm{I} 3 \frac{1}{2} \mathrm{~mm}$., robust, black, densely covered above with short fulvous pubescence, very bright orange-fulvous on thorax; on abdomen thinner, showing the black shining surface through, but the hind margins of segments 2 to 6 broadly testaceous, and covered by fulvous hair-bands; face, cheeks, pleura and ventral surface generally with white hair; legs also with white hair, but the knee-tufts ochreous, hair on outer side of tibiae slightly yellowish, and that of inner side of tarsi pale orange; small joints of tarsi ferruginous; spurs ferruginous. Eyes large, greyish-brown; facial quadrangle much longer than broad; clypeus light lemon yellow, the anterior edge ferruginous; labrum cream-color, densely covered with white hair; mandibles entirely black; antennae of only moderate length (about $7 \mathrm{~mm}$ ), black; flagellum brown-black beneath, with obscure lighter dots on the joints; tegulae ochraceous; wings dusky hyaline, nervures dark fuscous; second submarginal cell broader than high, but by no means so long as first; second transverso-cubital nervure with a curious double curve; first $\mathrm{r}$. $\mathrm{n}$. joining second s. m. not far from its end; third s. m. abruptly angled outwardly; apical plate of abdomen with the margins gently concave, not notched.

$q$ Looks like the $\delta$, but abdomen rather broader, and appearing entirely fulvous, the pubescence being thick and the tegument yellowish; hair of apex very bright orange-fulvous; hair of legs more decidedly fulvous-tinged, that on outer side of middle tibiae shining light fulvous, that on inner side of basal joint of hind tarsi ferruginous; scopa of hind legs fulvous-tinted, long and beautifully plumose; facial quadrangle about square; clypeus and labrum black, the hair of the latter tinged with yellowish; apical half of mandibles mainly fulvous, antennae dark, third joint longer than $4+5$, flagellum slightly brownish beneath. The double curve of the second t. c. is as in the $\vec{\sigma}$.

Hab.-New Mexico (F. H. Snow); no locality given, but the specimens are numbered 9I ( $\hat{\sigma})$ and $92(q)$. Named after the late Dr. C. L. Herrick, in recognition of his important work on the geology and zoology of New Mexico, carried on with indefatigable zeal for many years in spite of poor health and other difficulties. Superficially, this fine insect looks just like $M$. townsendi Ckll., but it is easily distinguished by the color of the antennae and of the hair of the scutellum. In the form and color of the abdomen the female $M$. herricki is like male M. townsendi. 
Melissodes epicharina, n. sp.

ㄴ.ngth nearly I $2 \mathrm{~mm}$., rather stout, with a long-oval, convex abdomen; black head and thorax with abundant white pubescence, becoming mouse-color dorsally, with much black on vertex; mesothorax except in front, and scutellum; eyes dark grey-brown; facial quadrangle broader than long; clypeus strongly and extremely and densely punctured; labrum covered with white hair; mandibles entirely black; flagellum bright ferruginous beneath beyond second joint; mesothorax moderately shining, with distinct, not very close punctures; scutellum more closely punctured; tegulae piceous, with light hair, and a few black hairs intermixed; wings strongly dusky, with a reddish tint; nervures piceous; second s. $\mathrm{m}$. broad but oblique, not narrowed above, receiving the first $r$. n. not far from its end; third s. m. narrowed rather more than half to marginal; legs black, small joints of middle tarsi, and hind tarsi, becoming ferruginous; hair of legs pale, ferruginous on inner side of tarsi, scopa of hind legs yellowish and strongly plumose; abdomen with light hair at base and sides, and long recumbent yellowish hairs on third and fourth segments, not abundant enough to alter the general dull black effect; on second segment is an even, rather broad, entire subapical band of cream-colored tomentum; two apical segments with black hair, tufts of white showing laterally; ventral segments fringed with pale hair, hair on last segment fuscous. The middle trochanters, and the adjacent base of their femora, have each a curious patch of ferruginous pubescence. 'Third joint of maxillary palpi long; fourth well-developed and cylindrical.

Hab.-Oak Creek Canyon, Arizona, $6000 \mathrm{ft}$., July (F. H. Snow). Very distinct by the one-banded abdomen, which gives it a curious superficial resemblance to Epicharis maculata Smith. A variety (Snow 443) has two bands, the additional one at the base of the second segment; in this example the eyes are seagreen. This may be called var. a.

\section{Melissodes tenuilarsis, n. sp.}

$\delta$ Length about $9 \mathrm{~mm}$; black, shining, head and thorax with rather abundant, long, dull white hair, nowhere mixed with black, the disc of thorax nude; eyes light grey; facial quadrangle nearly square, but broader above than below; front bare, very black and shining; clypeus bright lemon-yellow, its anterior edge black; labrum black; mandibles black, the apical half reddened; antennae nearly $9 \mathrm{~mm}$. long, entirely dark, the flagellum obscurely reddish beneath, without pale dots, the joints with more or less distinct longitudinal keels; mesothorax very shiny, with close well-defined punctures; at the posterior middle the punctures are sparse; scutellum similarly shiny and punctured, and with a little median 
longitudinal keel on its anterior half; tegulae piceous, with reddish margins; wings clear, almost milky, suffused with ferruginous towards the base; nervures ferruginous, second s. m. oblique, rather broader than high, receiving the first r. n. about the beginning of its last third; legs black, with scanty pale hair, claw joints ferruginous; spurs yellowish-white; middle and hind tarsi very long and slender; basal joint of hind tarsi flattened but very narrow, not hairy; abdomen black, the hind margins of the segments very broadiy whitish-hyaline; first segment with long dull white hair; the other segments with scanty pale hair, not forming definite bands, but apparently largely denuded; apical plate broad, deeply notched on each side; the usual four lateral spines; venter normal.

Hab. -Arizona (precise locality not given), Aug. I902 (F. H. Snow, I 797 ). Very easily known from $M$. confusa $\mathrm{Cr}$. and $M$. microsticta Ckll., by the slender tarsi.

\section{Melissodes hexacantha, n. sp.}

๙ Length about I I mm.; black, rather robust; antennae comparatively short, hardly $7 \mathrm{~mm}$. long; flagellum bright ferruginous beneath, except at base, but the apical margins of the joints narrowly darkened; third antennal joint more than twice as long as second; head and thorax with abundant light hair, whitish on face and beneath, pale ochreous dorsally, that on disc of scutellum and posterior disc of mesothorax black, but a band of ochreous between the black of mesothorax and scutellum; vertex with a very few black hairs at the sides; eyes pale greyish-green; facial quadrangle about square; clypeus strongly and extremely densely punctured, black, with a yellow transverse band adjacent to the anterior margin; labrum black; mandibles black, with a fulvous apical stripe; mesothorax shining, with strong rather close punctures; scutellum also strongly punctured; tegulae shining black, with light ochreous hair; wings slightly dusky, with a yellowish tint; nervures piceous; second s. m. very large, not narrowed above, but oblique, receiving the first $r$. n. not far from its end; third s. $m$. narrowed more than half to marginal; legs black, with yellowish-white hair; small joints of tarsi becoming ferruginous; spurs pale reddish; hair on inner side of tarsi pale dull orange; abdomen rather broad, with yellowish-white pubescence, forming subapical band on segments 2 to 4 , but no defined basal one on 2 ; hind margins of segments broadly brownish-hyaline; pubescence of fifth and sixth segments chocolate-color; apical plate squarely notched at sides; last three segments spined laterally, the first pair of spines small, the second very large, the third slender.

Hab.-Arizona (precise locality not stated), Aug. I902 (F. H. Snow, 447). 
The antennae are very much shorter than in M. tristis Ckll. On account of the clypeal marking, this might be confused with Xenoglossa pruinosa and $X$. angelica, but it is very easily known from these by the black tegulae and black hair on scutellum

Three other specimens are numbered (Snow coll.) 2026 (Oak Creek Canyon, Ariz., 6000 ft. August), 2027 (also Oak Creek Canyon) and ro53 (Arizona); the last is much worn. These show that the species varies as follows:-

Var. a. Thorax above without black hair, except a very few (probably not half a dozen) on posterior middle of mesothorax, the dark hair remaining at sides of vertex, however. Hair of fifth and sixth abdominal segments black. No. 2026 .

Var. b. Black hair very distinct on scutellum; lower half of clypeus yellow, with a pointed process of yellow directed upwards in the middle line. No. 2027 .

Var. c. Yellow of clypeus reduced to a small stripe, about one-third as long as width of clypeus. No. 1053 .

\section{Melissodes nigrosignata, $\mathrm{n} . \mathrm{sp}$.}

ㄴ. Length about I 2 to $\mathrm{I} 3 \mathrm{~mm}$; breadth of abdomen about $5 \mathrm{~mm}$, or slightly over, a rather large robust species, having about about the size, build, and pattern of abdominal banding of $M$. martini Ckll, but the abdominal bands are creamy-tinted, and considerably broader; the pattern referred to consists of broad entire bands on segments 3 and 4 , and 2 with an entire basal band, and a broadly interrupted median one, the lateral segments of the later pointed mesad, but not or hardly oblique. 'The basin of the first segment is covered with white tomentum (no dark intermixed), and the fifth and sixth segments are covered with black hair, long white hair showing at the extreme sides of the fifth; the hair of the venter is black, except quite at the sides, where it is white. Eyes reddish or grey; facial quadrangle a little broader than long: clypeus strongly and extremely densely punctured; mandibles with a brilliant orange apical stripe; antennae dark, flagellum faintly reddish beneath; hair of face, cheeks and pleura white, of head and thorax above pale ochreous; vertex with some black hairs, especially behind ocelli; hind part of mesothorax with a large patch of black hair, disc of scutellum also covered with black; tegulae black, with pale ochraceous hair; wings smoky, nervures black; second s. m. very large and broad, oblique, receiving the first $r$. $n$. near the beginning of its last third; third $t$. c. bent, not angled; legs black; hair of femora dull white; of anterior and middle tibiae dull white, with nearly half the outer side (divided obliquely) black, and the short hair on the inner side of anterior tibiae black; hair of anterior and 
middle tarsi black; of hind tibiae long (plumose on outer side) and stained with pale fulvous, some of the apical hairs on inner side tipped with black; basal joint of hind tarsi with long pale fulvous-tinged hair covering basal half outside, otherwise the hair is black, long, coarse and abundant on inner side. Third joint of maxillary palpi long.

Hab.-Oak Creek Canyon, Arizona, 6ooo ft., Aug., 2 ㅇ․ (Snow, r 988 and 1993.) Easily known for $M$. martini Ckll., by the color of the hair on the legs, the white hair showing at sides of fifth abdominal segments, and the narrower face. The black hair on thorax above, and other characters, separate it from $M$. blakei, Ckll. It really has a good deal of affinity with $M$. glenwoodensis Ckll., but is more robust, and is distinguished by the ochreous and black hair of thorax above, the hair on inner side of hind tibiae not black, their spurs longer, the hind one gently curved. It is conveniently distinguished from $M$. mysops Ckll., by the light hair of the pleura, and the bicolored middle tibiae.

\section{Melissodes semitristis, n. sp.}

$\hat{\delta}$ This is exactly what a hybrid between $M$. tristis and $M$. menuacha might be imagined to be like. It has precisely the stature, pubescence, etc. of $M$. menuacha, but the clypeus is wholly black (densely covered with white hair), the face is considerably broader, and the eyes are reddish-grey. The mandibles and labrum are black; there is no black hair on the disk of the thorax. From M. tristis it differs in having the stature of menuacha, and the nervures piceous or very dark brown; the width of the face agrees with tristis. Tegulae black, as in tristis. The insect is to tristis much as menuacha is to agilis.

Hab.-Oak Creek Canyon, Arizona, 6ooo ft., July. (F. H. Snow, 2009.)

\section{Melissodes pralauta, n. sp.}

๙. This looks just like $M$. semitristis, and was placed with it until the very different head was observed. The eyes are black and very prominent, and the face is narrowed below, so that the length of the facial quadrangle is considerably greater than its breadth at the lowest point; the face is very densely covered with long pure white hair, and the clypeus is of a curious greyish-white color; the mandibles are entirely black, except a small yellowish apical stripe; the labrum is black, with a large yellowish-white spot. The maxillary palpi are normal for Melissodes, with the last joint minute. The antennae are about $7 \mathrm{~mm}$. long, or rather more, with a rather stout flagellum, which is dark chestnut-red beneath. Tegulae black; nervures rufo-fuscous, wings perfectly hyaline, rather milky; second s. $m$. extremely large, larger than first, broader than high, receiving the 
first r. n. near the beginning of its last third; no black hair on head or thorax; the abundant hair of head, pleura and mesothorax entirely snow-white; that of metathorax, scutellum and abdomen more or less strongly stained with yellowish, that of the apical part of the abdomen quite ochreous; ocelli ruby-color; mesothorax shining and punctured; hind margins of abdominal segments broadly yellowish-hyaline, the hair-bands apical and only moderately conspicuous, the region between the bands being more or less hairy; the last three segments with prominent laleral teeth; legs black with white hair, only the claw-joints rufous; hair on inner side of basal joints of middle and hind tarsi clear ferruginous. The abdomen is not quite so broad as that of $M$. semitristis.

Hab. Oak Creek Canyon, Arizona, 6000 ft. (F. H. Snow, 2010). The peculiar appearance of the clypeus suggests that it may have failed to attain its natural color, but assuming this part to be naturally yellow; it is still impossible to identify the species with anything previously described. Seen from behind, the insect could very well be taken for $M$. menuacha, but in front the much darker antennae, narrower face, dark eyes and white pubescence are distinctive enough. M. Snowi Cr., which has the white pubescence in front, has it also behind, besides being much smaller.

\section{Melissodes duplocincta, n. sp.}

A species with a narrow abdomen and bluish-white pubescence, having a remarkable superficial resemblance to Synhalonia lippiae (Ckll.), but the subapical band on second abdominal segment, which in lippiae is reduced to a line on each side, is in duplocincta entire and even, so that the anterior part of the abdomen is girt by by two parallel clean-cut white bands, separated by a black interval about as wide as either of them. The third and fourth segments in the female, and the third to fifth in the male, have broad even white bands. The pubescence of the head, thorax and legs is white, but the disc of the scutellum is covered with short black hair, and some greyish-brown hair is mixed with the white on the mesothorax, producing in the $q$ a curious streaked or mottled appearance, as though the hair were stained; the hair of the vertex is entirely white in the $\delta$, but there are dusky hairs just behind the ocelli in the $q$.

$\delta$ Length about Io mm.; antennae long, about $7 \frac{1}{2} \mathrm{~mm}$; scape stout; flagellum slender, clear ferruginous beneath, except the apical two or three joints, which have not the form of Synhalonia; clypeus lemon-yellow, with a large squarish black mark at each side above; labrum pale yellow; base of mandibles entirely yellow; tegulae light fulvous; wings clear, stigma ferruginous, nervures fuscous; second s. m. almost exactly square, receiving the first r. n. almost at its 
end; third s. m. narrowed not quite half to marginal, its outer side curved, not angled; legs black, tarsi rather dark ferruginous; a raised, curved, transverse lamina on each side of venter near apex; spines at sides of sixth segment black, and unusually long; first segment of abdomen with much white hair, but the broad apical margin bare except at the extreme sides; other segments as described above; sixth covered with black hair, with a few light hairs at sides.

$\$$ Similar to the male, eyes pale greenish-grey; no yellow on clypeus, etc., the clypeus shining, with small punctures and little ridges, a sort of strawberry surface; middle of mandibles reddened; flagellum red beneath except basal joint; base of third abdominal segment broadly dark dull reddish, the two apical segments with black hair, a good deal of white at extreme sides of fifth; venter reddened basally; scopa on hind legs glistening white.

Hab.-Bill Williams' Fork, Arizona, August (F. H. Snow), one of each sex. $M$. duplocincta runs in my tables ( $q$ ) to the vicinity of $M$. pecosella, to which it is allied, but from which it is easily known by the narrower, bluish white (not creamy) abdominal bands, and the light reddish tegulae The width of the face is about the same. From $M$. intermediella it is separated by the shape of the abdomen, the whiter and more even abdominal bands; the square (not oblique) second s. m., with the first r. n. joining nearer the end; and the light reddish, tegulae (they are very dark in intermediella). The clypeus also is very shiny, whereas in intermediella it is very densely punctured and dullish. The male duplocincta runs to the vicinity of $M$. parosela, Ckll.; but the latter is smaller, with the hair of the thorax in front light fulvous, the tarsi clearer red, etc.

Xenoglossa strenua, $\mathrm{Cr}$, var. Kansensis, n. var.

$\delta$ Rather larger; legs dark reddish-fuscous, the anterior legs at most ferruginous but then dull-colored, very different from the typical bright red; tomentum of apical abdominal segments pale cinereous or whitish, not at all ochreous or fulvous.

Hab.-Clark Co., Kansas, I962 ft., June (F. H. Snow, I 186); Morton Co., Kansas, $3200 \mathrm{ft}$., June I902 (F. H. Sno ï', 439); Wallace Co., Kansas, $3000 \mathrm{ft}$. (F. H. Snow, г79г.) 


\section{THE TUSSOCK MOTH IN ROCHESTER, N. Y.}

Because of the destruction which has been wrought on shade trees by the tussock moth, the Board of Park Commissioners has declared war against the pest and the school children of the city are now enlisting in a war of extermination on the cocoons. The crusade is being conducted on the lines followed in the famous hunt of eleven years ago, when Rochester was so thoroughly cleaned of cocoons that not until the present year have the ravages of the past become serious again. The school children will be paid seven cents a quart for the cocoons, each quart to contain about 400 egg masses and weigh $2 \frac{1}{2}$ ounces. Five hundred dollars has been appropriated by the park board for the purpose. In addition to the regular payments, there will be six special prizes of $\$ 5$ each to the six boys making the highest records. It is an interesting calculation to figure how many caterpillars will be destroyed by this plan if the fund be exhausted. At seven cents a quart $\$ 470$ will buy 67 I 4 quarts of egg masses. Each quart must contain at least 375 egg masses, or a total of $2,5^{17}, 75^{\circ}$ egg masses in the 67 I 4 quarts. Professor Slingerland of Cornell University estimated that each egg mass would produce 200 caterpillars, so that $2,5^{\mathrm{I}} 7,740 \mathrm{egg}$ masses would produce 503,550,000 caterpillars next spring. Approximately, therefore, 500,000,000 caterpillars will be destroyed by the expenditure of the $\$ 500$, which is at the rate of $\$ \mathrm{I}$ a million, or $\mathrm{I} 0,000$ caterpillars for a cent. In the cocoon hunt of eleven years ago the first prize was won by a boy who was credited with collecting more than 2,000,000 cocoons, and his nearest competitor had more than $1,500,000$ to his credit. It was estimated that the pupils of one school alone had destroyed 7,500,000,000 caterpillars. No one else had figured out how many caterpillars were killed by the work of all the schools, but it was sufficient to keep the city clear of the pest for more than a decade. In view of these facts members of the park board do not agree with the State entomologist at Albany, who in a recent bulletin belittles the value of such a crusade. (Boston Evening Transcript.) 

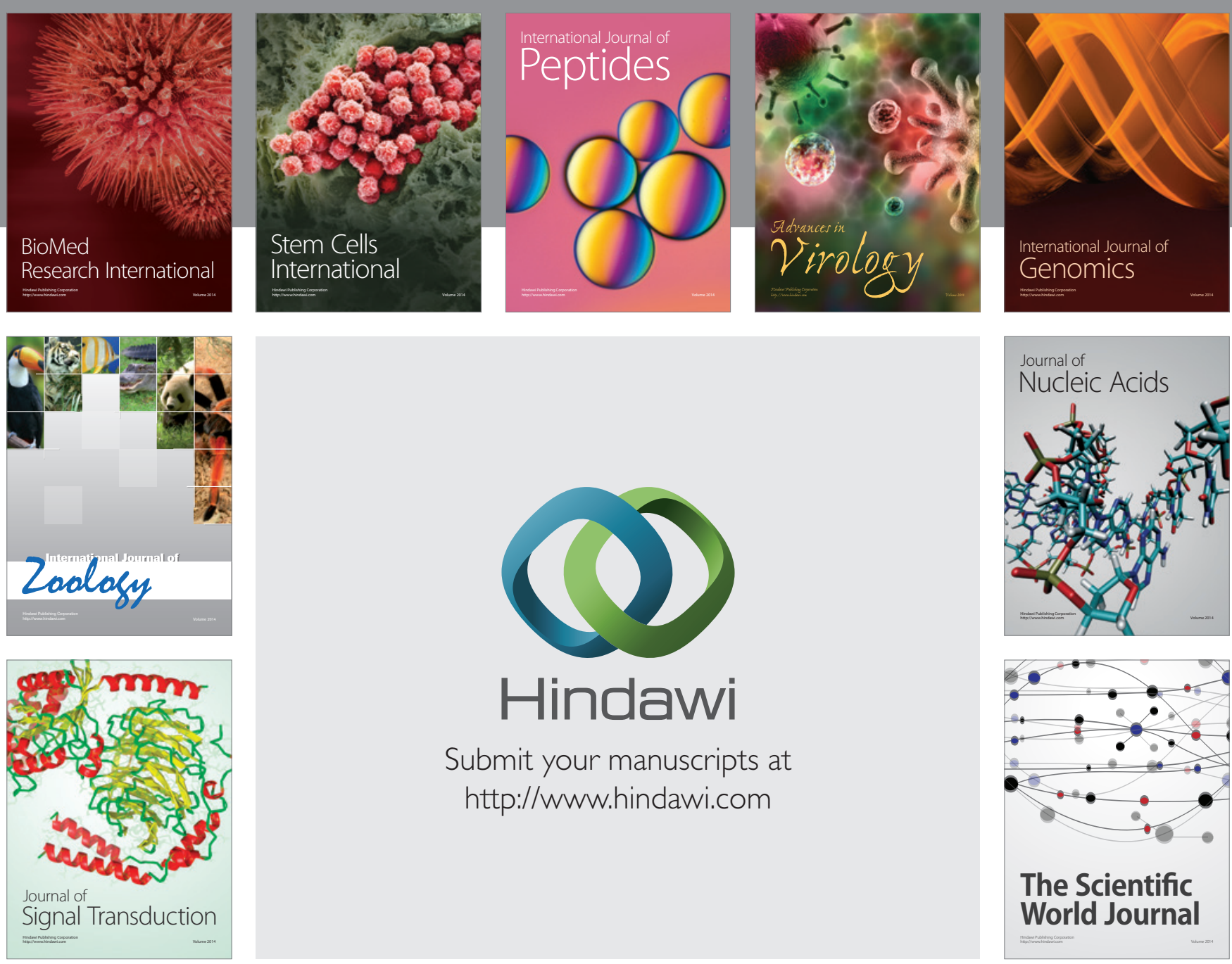

Submit your manuscripts at

http://www.hindawi.com
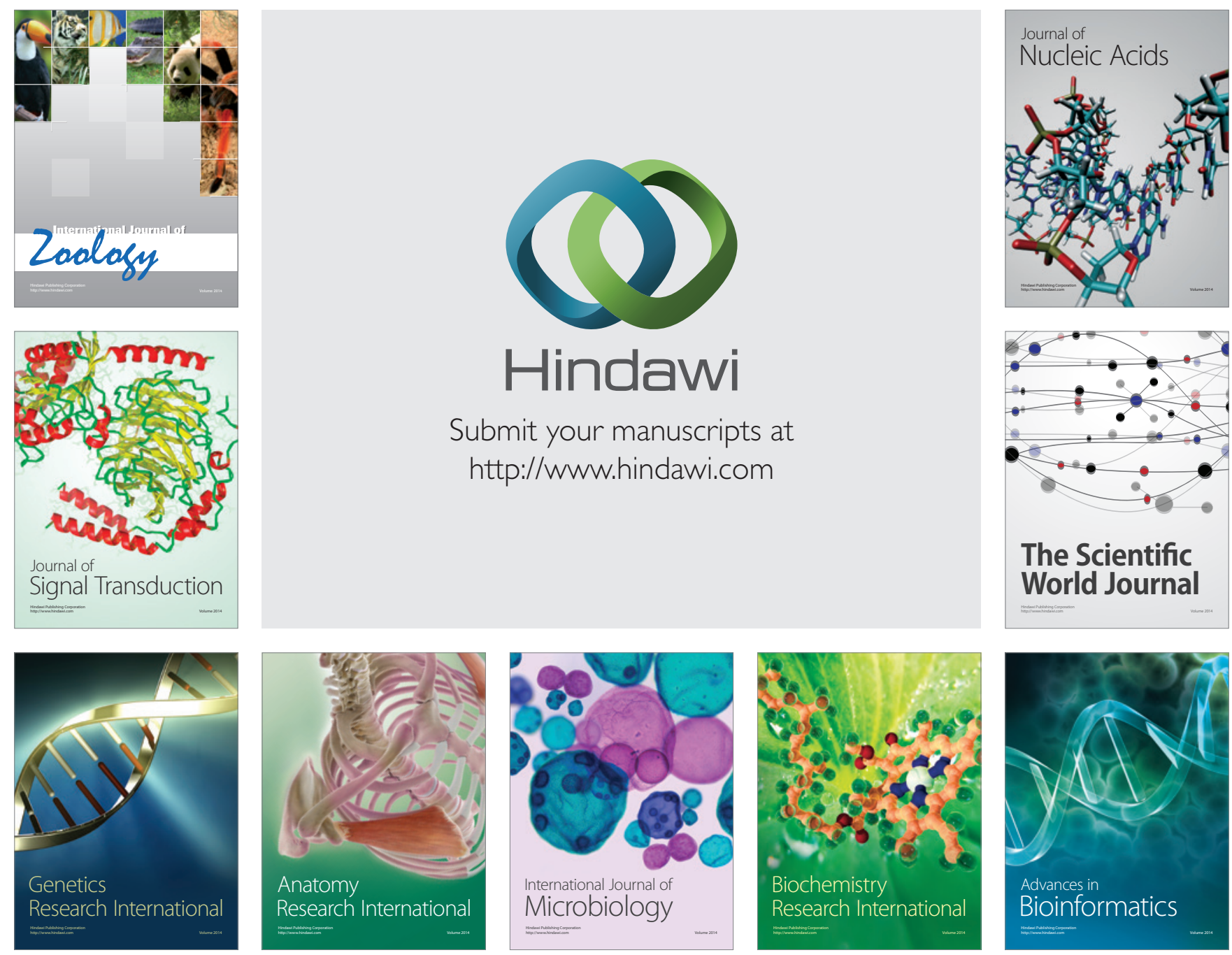

The Scientific World Journal
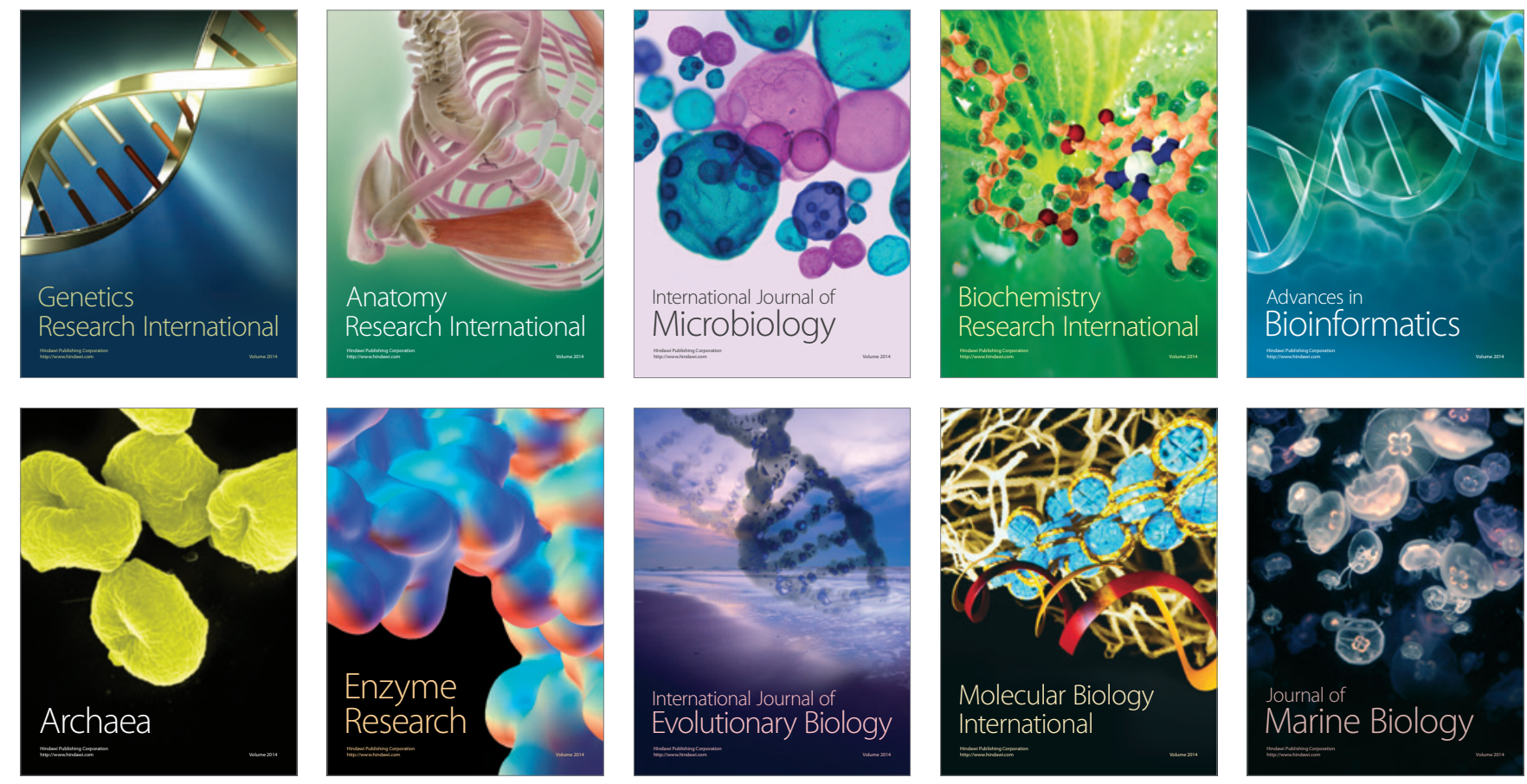